\title{
Isolasi dan Karakterisasi Bakteri Pengikat Nitrogen Tanah Gambut Hutan Dari Kecamatan Trumon Aceh Selatan
}

\author{
Syafrina Sari Lubis' ${ }^{1)}$, Arif Sardi' ${ }^{2}$, Feizia Huslina ${ }^{3)}$, Maria Lisa ${ }^{4)}$ \\ ${ }^{1}$ Program Studi Biologi, Fakultas Sains dan Teknologi, UIN Ar-Raniry Banda Aceh \\ email: syafrinasarilbs@ar-raniry.ac.id \\ ${ }^{2}$ Program Studi Biologi, Fakultas Sains dan Teknologi, UIN Ar-Raniry Banda Aceh \\ email: arif.sardi@ar-raniry.ac.id \\ ${ }^{3}$ Program Studi Biologi, Fakultas Sains dan Teknologi, UIN Ar-Raniry Banda Aceh \\ email: feizia.huslina@ar-raniry.ac.id \\ 4email: maria_lisa9888@yahoo.com
}

APA Citation: Lubis, S.,S., Sardi, A., Huslina, F., \& Lisa, M. (2020). Isolasi dan Karakterisasi Bakteri Pengikat Nitrogen Tanah Gambut Hutan Dari Kecamatan Trumon Aceh Selatan. Quagga: Jurnal Pendidikan dan Biologi, 12(2), 117-129. doi: 10.25134/quagga.v12i2.2794.

Received: 04-05-2020

Accepted: 04-06-2020

Published: 01-07-2019

\begin{abstract}
Abstrak: Isolasi bakteri pengikat nitrogen perlu dilakukan pada berbagai ekosistem. Tanah gambut merupakan ekosistem dengan keragaman mikroba yang cukup tinggi. Penelitian ini bertujuan untuk mendapatkan isolat bakteri pengikat nitrogen dan karakterisasinya dari tanah gambut Kecamatan Trumon Aceh Selatan. Sampel tanah diambil dari empat stasiun dengan tipe tanah gembur dan liat, kedalaman bervariasi mulai 0-15 cm, 15 $30 \mathrm{~cm}, 30-50 \mathrm{~cm}$. Isolasi dilakukan dengan metode cawan sebar menggunakan media Jensen. Terdapat 25 isolat bakteri pengikat nitrogen, koloni berwarna putih transparan dan merah muda. Bentuk sel coccus dan basil. Berdasarkan hasil pewarnaan gram 9 isolat gram negatif dan 16 isolat gram positif. Hasil uji biokimia terhadap 14 isolat terpilih diperoleh pada uji Triple Sugar Iron Agar sebanyak 11 isolat memfermentasi glukosa dan 3 isolat tidak mampu memfermentasi glukosa. Semua isolat BPN tidak mampu memproduksi $\mathrm{H}_{2} \mathrm{~S}$. Pengujian sitrat diperoleh 9 isolat bereaksi positif dan 5 isolat bereaksi negatif. Terdapat 12 isolat menunjukkan hasil positif pada uji katalase, dan 2 isolat bersifat negatif. Hasil uji motilitas 8 isolat bersifat motil dan 6 isolat non motil. Pada pengujian urease semua isolat bereaksi positif, hal ini menunjukkan semua isolat yang diperoleh berpotensi dikembangkan sebagai biofertilizier
\end{abstract}

Kata kunci: Tanah Gambut; Bakteri Pengikat Nitrogen

Abstract: Isolation of nitrogen-fixing bacteria from various ecosystems is paramount. Peat soil is an ecosystem which has a high diversity of microbes. This study aimed at isolating nitrogen-fixing bacteria from peat soil at Trumon, South Aceh and evaluate their characteristics. Soil samples were collected from four stations that indicated loose and clay soil types, with 0-15 cm, $15-30 \mathrm{~cm}, 30-50 \mathrm{~cm}$ depth. Isolation was carried out by spread plate method using Jensen media. Twentyfive isolates of nitrogen-fixing bacteria were obtained. Their colony characteristics were coccus, bacil, transparent and pink. Nine Gram-negative isolates and sixteen Gram-positive isolates were identified on the basis of the Gram stain test. Biochemical tests were performed on fourteen isolates. Eleven isolates were positive in Triple Sugar Iron Agar (TSIA) test while three isolates were negative. All isolates cannot produce $\mathrm{H}_{2} \mathrm{~S}$. Nine isolates were positive in citrate test while five isolates were negative. On the other hand, twelve isolates were catalase positive and two isolates were negative. Eight isolates were motile and others were non-motile were identified by motility test. All isolates were urease positive. This study revealed that all isolates are potential bacteria that can be developed as biofertilizers

Key words: Peatlands; Nitrogen fixing Bacteria

\section{PENDAHULUAN}

Indonesia memiliki luas lahan gambut sekitar adalah 14.905.574 ha. Lahan gambut tersebar pada 3 Pulau yaitu Sumatera sekitar 4.778.004 ha, Kalimantan 4.778.004 ha, dan Papua mempunyai lahan gambut sekitar 3,69 juta hektar (Ritung dan Sukarman, 2016). Lapisan permukaan pada tanah gambut mengandung bahan-bahan organik dengan kandungan karbon (C) organik mencapai $60 \%$ $\mathrm{C}$ berasal dari berat keringnya. Kategori tanah gambut antara lain bila terdapat kandungan $\mathrm{C}$ organik minimum $12 \%$ dengan ketebalan gambutnya minimal $50 \mathrm{~cm}$. Setiap ketebalan satu meter diperkirakan tanah gambut menyimpan 400 hingga 700 ton C organik. 
Selain itu, tanah gambut juga mengandung unsur hara makro dan mikro. Unsur hara makro meliputi Posfor (P), Kalium (K), Kalsium (Ca), dan Magnesium $(\mathrm{Mg})$. Sedangkan unsur hara mikro, yaitu Tembaga (Cu), Seng ( $\mathrm{Zn})$, Mangan (Mn), dan Besi (Fe) (Agus et al., 2016).

Ekosistem rawa gambut merupakan sumber keanekaragaman hayati, tidak hanya flora dan fauna tetapi juga mikroba. Menurut Pratiwi et al (2018), keragaman jenis dan jumlah mikroba pada suatu ekosistem merupakan indikasi terhadap kualitas ekosistem, sehingga data yang diperoleh dapat digunakan untuk mengambil langkah yang tepat dalam pengelolaan tanah gambut dalam berbagai bidang. Beberapa mikroba yang menguntungkan bagi tanaman yang ditemukan di hutan rawa gambut antara lain mikoriza, fungi endofit, bakteri pelarut fosfat, mikrob perombak bahan organik dan bakteri pengikat nitrogen ( $\mathrm{N}$-fixer) (Yuwati, 2016). Selain itu mikroorganisme pada tanah gambut beranekaragam dan memiliki peranan penting sebagai dekomposer, penyedia unsur hara bagi tanaman, penghasil enzim. (Mahdiyah, 2015).

Bakteri Pengikat Nitrogen (BPN) merupakan kelompok bakteri yang memiliki enzim nitrogenase yang mampu mengikat nitrogen (terutama $\mathrm{N}_{2}$ ) bebas dari atmosfer kemudian direduksi menjadi senyawa amonia $\left(\mathrm{NH}_{4}\right)$ dan ion nitrat $\left(\mathrm{NO}_{3}-\right)$ (Yuwati, 2016). BPN digolongkan ke dalam mikroba penyusun pupuk hayati yang terdiri dari dua jenis, yaitu simbiosis dengan sistem perakaran dan non simbiosis (hidup bebas pada lingkungan). BPN yang bersimbiosis antara lain Rhizobium, sedangkan bakteri pengikat nitrogen yang non simbiosis ialah Azotobacter dan Azosprillum. Jenis lainnya yaitu Streptomyces dan Lactobacillus sp. yang mengandung enzim pemecah selulosa sehingga mempercepat penguraian bahan organik dan meningkatkan hara tanah (Karina, 2016). BPN tersebar pada habitat tanah subur dan tanah marginal dengan keragaman dan populasi yang berbeda (Widawati, 2015). Tanah gambut merupakan tanah marjinal yang memiliki kesuburan rendah dengan ciri $\mathrm{pH}$ rendah (3.0 - 5.0), dan kandungan air yang tinggi (Erlansyah 2017).

Menurut data dari Indonesia Forest and Climate Support (IFACS, 2014), di Aceh Selatan terdapat sejumlah kawasan konservasi dan kawasan lindung yang telah ditetapkan oleh pemerintah, seperti Taman Nasional Gunung Leuser dan Suaka Alam Trumon Singkil serta hutan rawa gambut dengan kandungan karbon tinggi. Daerah pada kawasan ini memiliki nilai konservasi yang tinggi baik dari segi keanekaragaman spesies maupun dari segi ekosistem. Penelitian ini bertujuan untuk mendapatkan isolat bakteri pengikat nitrogen dan karakterisasinya dari tanah gambut Kecamatan Trumon Aceh Selatan.

\section{METODOLOGI PENELITIAN}

Penelitian dilakukan pada Laboratorium Mikrobiologi Jurusan Biologi Universitas Islam Negeri Ar-Raniry pada bulan November 2019 hingga Januari 2020. Lokasi pengambilan sampel dilakukan di hutan area gambut kelapa sawit terbuka pada gampong Teupin Tinggi Kecamatan Trumon, Aceh Selatan. Pengambilan sampel dilakukan pada 4 stasiun berbeda, yaitu

A. Stasiun I lahan yang ditanami sawit dengan tipe tanah gembur ( $\mathrm{N} 02^{\circ} 40^{\prime} 06$. 70" E $097^{\circ} 39^{\prime} 16.29$ "), sebanyak 3 titik A (kedalaman 0-15 cm), B (kedalaman $15-30 \mathrm{~cm}$ ), C (kedalaman $30-50 \mathrm{~cm}$ )

B. Stasiun II lahan yang ditanami sawit namun dengan tipe tanah liat $\left(\mathrm{N} 02^{\circ} 40^{\prime}\right.$ 06. 49” E $097^{\circ} 39^{\prime}$ 17. 17”), sebanyak 3 titik D (kedalaman 0-15 cm), E (kedalaman $15-30 \mathrm{~cm}$ ), dan F (kedalaman $30-50 \mathrm{~cm}$ ).

C. Stasiun III lahan yang tidak ditanami sawit dengan tipe tanah gembur $\left({\mathrm{N} 02^{\circ}}^{\circ}\right.$ 40' 06. 75" E $\left.097^{\circ} 39^{\prime} 15.48^{\prime \prime}\right)$, sebanyak 3 titik $\mathrm{G}$ (kedalaman 0-15 cm), $\mathrm{H}$ (kedalaman $15-30 \mathrm{~cm}$ ), dan I (kedalaman $30-50 \mathrm{~cm}$ ).

D. Stasiun IV lahan yang tidak ditanami

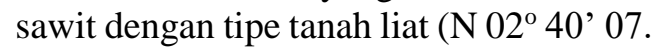
12" E $\left.097^{\circ} 39^{\prime} 14.67^{\prime \prime}\right)$, sebanyak 3 titik $\mathrm{J}$ (kedalaman 0-15 cm), K (kedalaman 15$30 \mathrm{~cm}$ ), dan L (kedalaman 30-50 cm).

\section{Pengambilan sampel}

Masing-masing sampel diambil sebanyak $0,5 \mathrm{~kg}$ pada kedalaman tanah yaitu $0-15 \mathrm{~cm}$ (titik A, D, G, J), 15-30 cm (titik B, E, H, K), 30-50 $\mathrm{cm}(\mathrm{C}, \mathrm{F}, \mathrm{I}, \mathrm{L})$ dengan menggunakan paralon diameter $5 \mathrm{~cm}$ yang telah digariskan ukuranukurannya. Paralon ini ditancapkan pada sampel tanah gembur dan tanah liat di 4 stasiun berbeda hingga kedalaman $50 \mathrm{~cm}$. Kemudian paralon 
diangkat dan diambil sampel tanah berdasarkan ukuran yang telah digariskan. Sampel yang telah diambil disimpan di dalam botol sampel steril dan segera dibawa ke laboratorium (Kaburuan $e t$ al., 2014). Pada lokasi pengambilan sampel dilakukan pengukuran $\mathrm{pH}$, suhu tanah dan kelembaban tanah.

\section{Pengukuran suhu}

Bagian ujung termometer tanah dimasukkan sampai pada kedalaman tanah $15 \mathrm{~cm}, 30 \mathrm{~cm}$, dan $50 \mathrm{~cm}$, tunggu beberapa saat hingga alat menunjukkan angka konstan. Kemudian dilihat dan dicatat angka yang muncul pada thermometer.

\section{Pengukuran pH dan Kelembaban tanah}

Ujung alat soil tester dimasukkan kedalam tanah yang diukur dengan kedalaman yang telah ditentukan, kemudian ditekan tombol. Angka yang muncul pada permukaan atas menunjukkan nilai $\mathrm{pH}$, dan angka yang muncul dibawah menunjukkan nilai dari kelembaban tanah.

\section{Isolasi Bakteri}

Sebanyak 1 gr sampel tanah dimasukkan ke dalam tabung reaksi berisi $9 \mathrm{ml}$ akuades steril, lalu dihomogenkan dengan vortex serta diberi label dengan seri tabung pengenceran $10^{-1}$. Selanjutnya $1 \mathrm{ml}$ larutan tanah dipindahkan ke tabung reaksi selanjutnya yang berisi $9 \mathrm{ml}$ akuadest steril menggunakan pipet volume $1 \mathrm{ml}$. Kemudian vortex kembali dan diberi label $10^{-2}$. Dilakukan pengenceran hingga $10^{-5}$. Tahap selanjutnya larutan tanah pengenceran dengan serial $10^{-5}$ diambil $0,1 \mathrm{ml}$ dari pengenceran $10^{-5}$ untuk ditumbuhkan pada cawan petri dengan cara disebar di atas permukaan medium Jensen secara aseptik, hal ini dilakukan dengan tiga kali ulangan. Langkah selanjutnya diinkubasi dengan posisi terbalik selama 5 hari pada suhu $37^{\circ} \mathrm{C}$ dan diamati setiap 24 jam sekali (Fajrin et al., 2017).

Pertumbuhan BPN dapat diamati dengan adanya pertumbuhan koloni pada medium Jensen. Pemurnian koloni dilakukan dengan metode streak plate pada media Jensen dan diinkubasi kembali. Kegiatan ini diulang sampai diperoleh koloni yang terpisah. Pengamatan morfologi koloni dilakukan dengan bentuk, warna tepian dan elevasi (Kaburuan et al., 2014).

\section{Pengujian Gram}

Isolat murni yang diperoleh dilakukan pewarnaan Gram dengan menggoreskan 1 ose isolat bakteri pada kaca preparat hingga tidak menggumpal. Selanjutnya diteteskan cat Gram A (Kristal violet) 1 tetes selama 1 menit, bilas dengan air mengalir sampai warna luntur, lalu fiksasi pada api spiritus. Tahap berikutnya ditambahkan 1 tetes Gram B (Iugol) ke preparat dan didiamkan selama 1 menit. Setelah 1 menit, dibilas dengan Gram C (Alkohol $96 \%$ ) sampai semua zat warna hilang hingga kristal violet tidak dapat dibilas lagi. Kemudian basuh kembali dengan air mengalir dan fiksasi pada api spiritus. Selanjutnya tambahkan sebanyak 1 tetes larutan Gram D (Safranin) pada preparat dan tunggu hingga 45 detik. Tahap akhir bilas preparat dengan air mengalir dan keringkan permukaannya. Setelah itu amati perubahan warna dan bentuk sel pada mikroskop (Fajrin et al., 2017).

\section{Uji Motilitas (Sulfide Indole Motility)}

Sebanyak 1 ose Isolat BPN diambil lalu diinokulasikan dengan cara ditusuk pada media Sulfate Indole Motility (SIM). Kemudian diinkubasikan pada suhu $37^{\circ} \mathrm{C}$ selama $2 \times 24$ jam.

\section{Uji Katalase}

Isolat BPN diambil sebanyak 1 ose dengan menggunakan jarum ose kemudian digoreskan pada kaca preparat lalu ditetesi reagen $\mathrm{H}_{2} \mathrm{O}_{2}$. Jika terbentuk gelembung gas maka hasilnya positif, dan hasil negatif jika tidak terbentuk gelembung gas.

\section{Uji Sitrat (Simmons Citrat Agar)}

Isolat BPN diambil sebanyak 1 ose dengan menggunakan jarum ose kemudian digoreskan pada media SCA yang telah dimiringkan. Diinkubasi selama 28-48 jam. Bila terjadi perubahan warna media dari awalnya berwarna hijau menjadi biru menunjukkan reaksi positif, tetapi bila tidak berubah warna menunjukkan reaksi negatif.

\section{Uji Urea}

Isolat BPN diambil sebanyak 1 ose dengan menggunakan jarum ose kemudian dicelupkan kedalam tabung reaksi yang berisi medium urea base agar. Diinkubasi selama 1x24 jam. Bila terjadi perubahan warna media merah jingga 
menjadi merah ungu, berarti reaksi positif menunjukkan terjadinya hidrolisis urea.

\section{Uji Hidrolisis Gula (Triple Sugar Iron Agar)}

Isolat BPN diambil sebanyak 1 ose diambil dengan menggunakan ose cincin/ose bengkok kemudian diinokulasikan dengan cara ditusukkan pada media Triple Sugar Iron Agar (TSIA). Selanjutnya diambil lagi 1 ose isolat digoreskan zig zag pada bagian miring media. Kemudian diinkubasikan pada suhu $37^{\circ} \mathrm{C}$ selama 48 jam. Perubahan warna yang terjadi setelah diinkubasi ialah warna media menjadi warna kuning yang menandakan asam. Sedangkan apabila warna media menjadi merah menandakan basa, dan apabila warna menjadi hitam menandakan terbentuknya $\mathrm{H}_{2} \mathrm{~S}$, dan apabila media terangkat menunjukkan bahwa mikroba tersebut mampu untuk memproduksi gas (Ismiati, 2018).

Data yang telah diperoleh lalu dianalisis secara deskriptif, yaitu dengan cara memberikan penjelasan atau penggambaran dari bakteri yang didapat hasil isolasi, dan karakterisasi morfologi koloni, morfologi sel, \& uji biokimia (Kaburuan et al., 2014).

\section{HASIL DAN PEMBAHASAN Karakter fisik tanah gambut}

Kondisi tanah gambut pada lokasi pengambilan sampel berwarna coklat kehitaman, berair, serta tekstur tanah yang halus. Kelembaban tanah yang rendah di stasiun 1 dikarenakan oleh tipe tanah yang gembur dan berada pada area tanaman kelapa sawit yang banyak menyimpan air. Beda halnya dengan kelembaban pada stasiun II yang berada pada area tanaman kelapa sawit namun bertipe tanah liat, yang penyimpanan air nya tidak terlalu banyak. Hasil penelitian lain menunjukkan hasil yang berbeda pada kawasan gambut hutan lindung terdapat kandungan air yang lebih tinggi hingga mencapai 93,2\% (Pratiwi et al., 2018). Kecamatan Trumon Aceh Selatan memiliki tipe kematangan gambut yang sebagian besarnya bersifat saprik dan hemik, dengan ketebalan gambut 51-125 cm, dan $\mathrm{pH}$ tanah 3,5-4,5. Tanah gambut mempunyai sifat asam, kemasaman gambut ini dipengaruhi oleh kandungan asam organik pada koloid gambut. Kemasaman tanah gambut ini juga disebabkan oleh adanya dekomposisi bahan-bahan organik yang terdapat pada kondisi anaerob sehingga menyebabkan terbentuknya senyawa fenolat dan karboksilat (Mahdiyah, 2015).

\section{Isolat BPN lahan gambut}

Isolasi BPN dari lokasi penelitian diperoleh 25 isolat. Data hasil isolasi dan pengukuran faktor fisik tanah tanah gambut dapat dilihat pada tabel 1 .

Berdasarkan tabel 1 dapat dilihat populasi bakteri lebih banyak terdapat pada permukaan tanah $(0-15 \mathrm{~cm})$ dibandingkan pada kedalaman (15-30 dan 30-50 cm. Pada kedalaman 30-50 cm populasi bakteri lebih rendah dibandingkan pada permukaan tanah pada kedalaman ini terdapat genangan air tanah, sehingga ketersediaan oksigen semakin berkurang. Pada penelitian Pratiwi et al. (2018), menunjukkan kadar air pada kedalaman 20-50 $\mathrm{cm}$ konsisten lebih tinggi dibandingkan kadar air pada lapisan 0-20 cm. Populasi mikroba mengalami penurunan pada tiap kedalaman tanah, hal ini berkaitan dengan ketersediaan oksigen yang semakian berkurang karena tingginya kadar air pada lapisan tanah bagian bawah. Adanya genangan air ini menjadikan lingkungan menjadi semakin anaerob. Hanya mikroba yang memiliki kemampuan bertahan di lingkungan anaerob yang mampu tumbuh di tanah gambut tergenang air. Pada permukaan tanah terdapat populasi bakteri yang cukup tinggi, disebabkan pada bagian terdapat perakaran tanaman. Metabolit yang dikeluarkan akar menjadi substrat dan suplai nutrisi pada populasi mikroba yang berada dekat perakaran tanaman. Populasi bakteri yang lebih banyak ditemukan pada daerah perakaran tanaman dibandingkan pada daerah tanpa tanaman disebabkan karena perkembangan mikroba dipengaruhi oleh aktivitas dari metabolisme perakaran tanaman. Akar tanaman melakukan aktivitas metabolismenya yang disebut dengan eksudat ke dalam tanah. Eksudat ini difungsikan oleh bakteri di dalam tanah sehingga bakteri tersebut mampu bertahan hidup serta memperbanyak diri. Hal ini menyebabkan populasi bakteri pada daerah perakaran tanaman menjadi sangat tinggi (Sari, 2015).

Isolasi BPN dari tanah gambut Taman Nasional Tesso Nilo, Riau mendapatkan 47 isolat bakteri pengikat nitrogen simbiotik, dan mempunyai ciri berwarna putih Selanjutnya, penelitian dari tanah gambut Semenanjung Kampar juga melaporkan memperoleh sebanyak 
37 isolat. Kemudian, penelitian dari hasil isolasi yang dilakukan dari tanah kebun Biologi di Wamena Papua juga menemukan 11 isolat (Rohyani et al., 2014). Demikian selanjutnya penelitian yang dilakukan pada tanah gambut
Kecamatan Tambang Kabupaten Kampar mendapatkan hasil 12 isolat oleh (Irfan, 2014). Penelitian BPN hasil isolasi dari tanah gambut Cagar Biosfer Giam Siak Kecil Bukit Batu juga mendapatkan 31 isolat (Kaburuan et al., 2014).

\begin{tabular}{|c|c|c|c|c|c|c|}
\hline \multicolumn{2}{|c|}{ Lokasi } & $\begin{array}{l}\text { Kedalaman } \\
\text { Tanah }\end{array}$ & $\begin{array}{l}\text { eter fisik tanah gan } \\
\text { Jumlah Isolat }\end{array}$ & $\begin{array}{c}\text { dan } \mathrm{j} \\
\mathbf{p H}\end{array}$ & $\begin{array}{l}\text { lah isol } \\
\text { Suhu }\end{array}$ & $\begin{array}{c}\text { Kelembaban } \\
\text { tanah }\end{array}$ \\
\hline \multirow{4}{*}{ 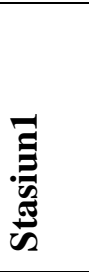 } & Titik & $0-15 \mathrm{~cm}$ & GA 1, GA 2, GA 3 & \multirow{4}{*}{5,3} & \multirow{4}{*}{$28^{\circ} \mathrm{C}$} & \multirow{4}{*}{4} \\
\hline & A & & & & & \\
\hline & $\begin{array}{l}\text { Titik } \\
\text { B }\end{array}$ & $15-30 \mathrm{~cm}$ & GB 1, GB 2, GB 3 & & & \\
\hline & $\begin{array}{l}\text { Titik } \\
\text { C }\end{array}$ & $30-50 \mathrm{~cm}$ & GC 1, GC 2 & & & \\
\hline \multirow{3}{*}{ 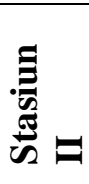 } & $\begin{array}{l}\text { Titik } \\
\text { D }\end{array}$ & $0-15 \mathrm{~cm}$ & $\mathrm{LD} 1, \mathrm{LD} 2, \mathrm{LD} 3$ & \multirow[t]{3}{*}{5,1} & \multirow[t]{3}{*}{$29^{\circ} \mathrm{C}$} & \multirow[t]{3}{*}{5} \\
\hline & Titik E & $15-30 \mathrm{~cm}$ & LE 1 & & & \\
\hline & Titik F & $30-50 \mathrm{~cm}$ & LF 1 & & & \\
\hline \multirow{3}{*}{ 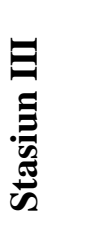 } & $\begin{array}{l}\text { Titik } \\
\text { G }\end{array}$ & $0-15 \mathrm{~cm}$ & GG 1 & \multirow[t]{3}{*}{5,1} & \multirow[t]{3}{*}{$28^{\circ} \mathrm{C}$} & \multirow[t]{3}{*}{5} \\
\hline & $\begin{array}{l}\text { Titik } \\
\mathrm{H}\end{array}$ & $15-30 \mathrm{~cm}$ & GH 1, GH 2 & & & \\
\hline & Titik I & $30-50 \mathrm{~cm}$ & GI 1, GI 2 & & & \\
\hline \multirow{3}{*}{ 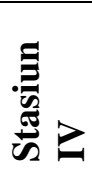 } & Titik J & $0-15 \mathrm{~cm}$ & $\mathrm{LJ} 1, \mathrm{LJ} 2, \mathrm{LJ} 3$ & \multirow{3}{*}{5,1} & \multirow{3}{*}{$29^{\circ} \mathrm{C}$} & \multirow{3}{*}{5} \\
\hline & $\begin{array}{l}\text { Titik } \\
\text { K }\end{array}$ & $15-30 \mathrm{~cm}$ & LK 1, LK 2 & & & \\
\hline & Titik L & $30-50 \mathrm{~cm}$ & LL 1, LL2 & & & \\
\hline
\end{tabular}

Mikroba pada tanah gambut dikenal dengan mikroba asidofilik. Mikroba ini berpotensi untuk dijadikan sebagai agen-agen biofertilizer, hal ini dikarenakan mikroba mempunyai peranan penting dalam proses dekomposisi berbagai bahan organik, dan memiliki pH 3-5. Penelitian yang dilakukan Irfan (2014), melaporkan bahwa memperoleh 12 isolat dari sampel tanah gambut pada kedalaman 0-100 cm dengan rataan $\mathrm{pH}$ nya 3,97 . Hubungan jumlah bakteri dengan $\mathrm{pH}$ tanah ialah $\mathrm{pH}$ tanah memegang peranan pada ketersediaan nutrisi bagi mikroorganisme. $\mathrm{pH}$ yang optimum pada bakteri yaitu minimum 4, sedangkan untuk maksimumnya yaitu 9. Akan tetapi, terdapat beberapa spesies yang mampu tumbuh dalam keadaan basa maupun masam. Selain itu, penelitian oleh Kaburuan et al., (2014) pada kedalaman gambut 0-40 cm melaporkan bahwa diperoleh isolat bakteri pengikat nitrogen sebanyak 31 isolat.
Pada penelitian ini jumlah isolat bakteri dari lahan gambut yang telah ditanami sawit menunjukkan hasil yang sama dengan yang diperoleh dari tanah gambut yang masih alami. Keberadaan mikroba pada tanah merupakan sebuah indikator kondisi sebuah ekosistem. Alih fungsi lahan gambut menjadi perkebunan sawit mendorong pertumbuhan mikroba karena pada lahan tersebut terjadi proses peningkatan nutrisi melalui proses pemupukan. Selain itu pada lahan gambut yang telah beralih fungsi terjadi peningkatan aerasi, sehingga permukaan tanah menjadi aerob dan menyebabkan mikroba lebih aktif dalam merombak bahan organik (Pratiwi et al., 2018). Hasil ini berbeda dengan pendapat Kononen (2018), bahwa pada lahan gambut yang telah terbuka atau mengalami alih fungsi lahan menjadi lahan pertanian terjadi penurunan aktivitas mikroba bila dibandingkan dengan hutan gambut yang masih alami. Tipe tanah dan jenis tanaman akan mempengaruhi jumlah populasi dari bakteri. Tidak hanya itu, tipe dan 
jenis tanah juga akan mempengaruhi struktur serta komunitas mikroba yang terdapat di dalam tanah (Pidjath et al., 2014).

\section{Karakteristik BPN}

Berdasarkan hasil isolasi dari sampel tanah gambut dengan menggunakan media selektif Jensen, diperoleh 25 isolat bakteri pengikat nitrogen. Bakteri pengikat nitrogen merupakan bakteri yang hidup bebas di alam serta dapat tumbuh baik pada media yang tidak mengandung nitrogen. Media Jensen merupakan media selektif yang digunakan dalam mengisolasi BPN. Hal ini dikarenakan media tersebut mengandung nutrisi yang dibutuhkan oleh bakteri pengikat nitrogen, meliputi sukrosa, dipostassim fosfat, magnesium sulfat, sodium klorida, ferrous sulfat, sodium molibdat, serta kalsium karbonat. Huslina dan Harahap (2019), menyatakan media Jensen juga diformulasikan dan direkomendasikan untuk mendeteksi serta menumbuhkan bakteri pengikat nitrogen. Pada media Jensen ini, sukrosa berfungsi sebagai sumber energi bakteri, sedangkan sodium molibdatnya berguna untuk meningkatkan aktivitas dari pengikatan nitrogen. Selanjutnya, sodium klorida juga berfungsi untuk mempertahankan keseimbangan tekanan osmotik media. Kalsium berguna sebagai menstimulasi pembentukan nodul ketika muncul dalam bentuk klorida atau sulfat. Sehingga isolat yang tumbuh pada media ini dapat dipastikan merupakan bakteri pengikat nitrogen.

Hasil pengamatan morfologi koloni isolat BPN dalam penelitian ini memiliki warna yang putih transparan dan merah muda. Bentuk koloni terdiri dari bundar, tidak beraturan. Tepian koloni terdiri dari rata, berombak, dan tidak beraturan. Elevasi koloni terdiri dari cembung serta datar dan memiliki warna putih transparan dan merah muda. Sedangkan hasil pengamatan morfologi sel terdiri dari bentuk coccus dan basil. Hasil pengujian gram diperoleh terdapat 9 isolat gram negatif dan 16 isolat gram positif.

Hasil yang diperoleh ini sesuai dengan hasil pengamatan morfologi koloni yang didapatkan dalam penelitian Irfan (2014) yang menjelaskan bahwa morfologi koloninya berbentuk tidak teratur dan terdapat beberapa yang berbentuk batang dan bulat. Permukaan koloninya yang menyerupai kawah, membukit, timbul datar serta melengkung. Tepi koloni berombak berbelah, keriting, dan rata. Sedangkan untuk warna koloni diperoleh warna yang hampir semuanya berwarna putih dan hanya terdapat satu isolat berwarna kekuningan. Selain itu, hasil isolasi bakteri diazotrof (bakteri pengikat nitrogen) non simbiotik dari empat lokasi pengambilan sampel menunjukkan karakter morfologi koloni dan sel yang sangat bervariasi. Bentuk koloni dari isolat terdiri dari bulat dan tidak teratur, elevasi bervariasi cembung, datar dan tinggi dengan permukaan halus, halus mengkilap dan licin. Tepi koloni umumnya berombak dan rata, dengan warna koloni bervariasi seperti bening, putih keruh, putih susu, merah muda, orange dan krem (Islam et al., 2019).

Hasil isolasi BPN pada Cagar Biosfer Giam Siak Kecil Bukit Batu menjelaskan bahwa bentuk koloni berbentuk bulat, bulat dengan tepian kerang, bulat dengan tepian timbul, tidak beraturan, dan konsentris. Untuk tepiannya dijelaskan bahwa berbentuk licin, berombak dan berlekuk. Untuk elevasinya berupa timbul, datar dan cembung. Sedangkan untuk warna koloninya yaitu berwarna putih dan putih transparan (Kaburuan et al., 2014). Kemudian, dalam penelitian Mahdiyah (2015) juga menyatakan bahwa bentuk koloni berbentuk bulat, tepian yang rata, bergerigi, dan berombak. Untuk elevasinya yaitu cembung, datar dan cekung serta warna dari koloninya yaitu putih, krem, kuning, orange, kuning transparan dan ungu. Hal ini membuktikan bahwa bakteri yang dominan pada setiap jenis tanah dan pada setiap perakaran tanaman yaitu bakteri yang mempunyai bentuk koloni tidak beraturan, tumbuh pada dasar media dan berwarna putih susu serta bening (Pidjath et al., 2014). 
Tabel 2. Karakterisasi Bakteri Pengikat Nitrogen

\begin{tabular}{|c|c|c|c|c|c|c|c|}
\hline \multicolumn{6}{|c|}{ Morfologi Koloni } & \multicolumn{2}{|c|}{ Morfologi Sel } \\
\hline No. & $\frac{\vec{\sigma}}{0}$ & ف를 & है & $\begin{array}{l}\overline{0} \\
\frac{\pi}{6} \\
\frac{2}{x}\end{array}$ & $\underbrace{\pi}$ & 莣 & 苞 \\
\hline 1 & GA 1 & Bundar & rata & Cembung & $\begin{array}{c}\text { Putih } \\
\text { Transparan }\end{array}$ & Coccus & - \\
\hline 2 & GA2 & Bundar & Berombak & Datar & $\begin{array}{c}\text { Putih } \\
\text { Transparan }\end{array}$ & Coccus & + \\
\hline 3 & GA 3 & $\begin{array}{c}\text { Tak } \\
\text { beraturan }\end{array}$ & $\begin{array}{c}\text { Tak } \\
\text { beraturan }\end{array}$ & Datar & $\begin{array}{c}\text { Putih } \\
\text { Transparan }\end{array}$ & Coccus & + \\
\hline 4 & GB 1 & Bundar & Rata & Cembung & $\begin{array}{c}\text { Putih } \\
\text { Transparan }\end{array}$ & Coccus & + \\
\hline 5 & GB 2 & $\begin{array}{c}\text { Tak } \\
\text { beraturan }\end{array}$ & $\begin{array}{c}\text { Tak } \\
\text { beraturan }\end{array}$ & Datar & $\begin{array}{c}\text { Putih } \\
\text { Transparan }\end{array}$ & Basil & - \\
\hline 6 & GB 3 & Bundar & Rata & Cembung & $\begin{array}{c}\text { Putih } \\
\text { Transparan }\end{array}$ & Coccus & + \\
\hline 7 & GC 1 & Bundar & Rata & Cembung & $\begin{array}{c}\text { Putih } \\
\text { Transparan }\end{array}$ & Coccus & + \\
\hline 8 & GC 2 & $\begin{array}{c}\text { Tak } \\
\text { beraturan }\end{array}$ & $\begin{array}{c}\text { Tak } \\
\text { beraturan }\end{array}$ & Datar & $\begin{array}{c}\text { Putih } \\
\text { Transparan }\end{array}$ & Coccus & + \\
\hline 9 & LD1 & Bundar & Rata & Datar & $\begin{array}{c}\text { Putih } \\
\text { Transparan }\end{array}$ & Coccus & + \\
\hline 10 & LD 2 & $\begin{array}{c}\text { Tak } \\
\text { beraturan }\end{array}$ & Berombak & Datar & $\begin{array}{c}\text { Putih } \\
\text { Transparan }\end{array}$ & Basil & - \\
\hline 11 & LD 3 & Bundar & Rata & Cembung & $\begin{array}{c}\text { Putih } \\
\text { Transparan }\end{array}$ & Coccus & + \\
\hline 12 & LE 1 & Bundar & Rata & Datar & $\begin{array}{c}\text { Putih } \\
\text { Transparan }\end{array}$ & Coccus & + \\
\hline 13 & LF1 & Bundar & Rata & Cembung & $\begin{array}{c}\text { Putih } \\
\text { Transparan }\end{array}$ & Coccus & + \\
\hline 14 & GG1 & Bundar & Berombak & Datar & $\begin{array}{c}\text { Putih } \\
\text { Transparan }\end{array}$ & Coccus & + \\
\hline 15 & GH 1 & Bundar & Rata & Cembung & Merah muda & Coccus & + \\
\hline 16 & GH 2 & Bundar & Berombak & Datar & $\begin{array}{c}\text { Putih } \\
\text { Transparan }\end{array}$ & Coccus & + \\
\hline 17 & GI 1 & Bundar & Berombak & Datar & $\begin{array}{c}\text { Putih } \\
\text { Transparan }\end{array}$ & Coccus & + \\
\hline 18 & GI 2 & Bundar & Berombak & Datar & $\begin{array}{c}\text { Putih } \\
\text { Transparan }\end{array}$ & Coccus & - \\
\hline 19 & LJ 1 & Bundar & Berombak & Cembung & $\begin{array}{c}\text { Putih } \\
\text { Transparan }\end{array}$ & Coccus & + \\
\hline 20 & LJ 2 & $\begin{array}{c}\text { Tak } \\
\text { beraturan }\end{array}$ & Berombak & Datar & $\begin{array}{c}\text { Putih } \\
\text { Transparan }\end{array}$ & Basil & - \\
\hline 21 & LJ 3 & Bundar & Rata & Cembung & $\begin{array}{c}\text { Putih } \\
\text { Transparan }\end{array}$ & Basil & - \\
\hline 22 & LK1 & Bundar & Berombak & Datar & $\begin{array}{c}\text { Putih } \\
\text { Transparan }\end{array}$ & Coccus & - \\
\hline 23 & LK2 & Bundar & Rata & Cembung & $\begin{array}{c}\text { Putih } \\
\text { Transparan }\end{array}$ & Coccus & + \\
\hline 24 & LL1 & Bundar & Berombak & Cembung & $\begin{array}{c}\text { Putih } \\
\text { Transparan }\end{array}$ & Coccus & - \\
\hline 25 & LL 2 & Bundar & Rata & Datar & $\begin{array}{c}\text { Putih } \\
\text { transparan }\end{array}$ & Basil & - \\
\hline
\end{tabular}


Data tabel 2 juga dapat dilihat bahwa bentuk sel isolat BPN memiliki bentuk sel coccus sebanyak 20 isolat dan basil 5 isolat. Umumnya, bakteri mempunyai bentuk sel yang berbentuk bulat (coccus), batang (bacil), dan bengkok (spiral). Bentuk sel bakteri dapat digunakan untuk mencirikan morfologi suatu spesies. Seperti halnya pada penelitian Irfan (2014) memperoleh isolat bentuk sel coccus sebanyak 7 isolat dan bentuk sel basil sebanyak 5 isolat. Pada penelitian Kaburuan et al., (2014), memperoleh 3 isolat bentuk sel coccus, 22 isolat berbentuk basil, dan 6 isolat berbentuk spiral. Mahdiyah (2015), melaporkan bahwa memperoleh semua isolat dengan bentuk sel basil.

Selain itu, data dari tabel 2 memperlihatkan terdapat adanya bakteri Gram positif dan Gram negatif. Hasil pewarnaan Gram ini dipengaruhi oleh komposisi dinding sel pada bakteri. Pada proses pewarnaan, bakteri Gram negatif akan memiliki ciri-ciri tidak mampu mempertahankan warna ungu dari Kristal violet, dan mampu menyerap zat warna safranin sehingga tampak warna merah muda sampai merah pada ketika diamati dibawah mikroskop. Sedangkan untuk golongan bakteri Gram positif mampu mempertahankan warna ungu dari Kristal violet sehingga menghasilkan warna ungu pada saat diamati dibawah mikroskop. Pada bagian akhir proses pewarnaan juga akan diperoleh bentuk dari morfologi sel yang telah diisolasi (Pratita et al., 2012).

Pada penelitian lainnya hasil isolasi BPN pada areal kelapa sawit Kabupaten Kampar diperoleh 12 isolat yang keseluruhannya bersifat Gram negatif (Irfan, 2014). Isolasi bakteri pada Cagar Biosfer Giam Siak Kecil Bukit Batu mendapatkan isolat BPN sebanyak 31 isolat, yang 17 isolat Gram positif dan 14 isolat Gram negatif (Kaburuan et al., 2014). Selanjutnya Mahdiyah (2015), juga melaporkan dari penelitiannya bakteri dari tanah gambut penghasil enzim protease mendapatkan sebanyak 5 isolat, yang terdiri dari 4 isolat merupakan bakteri Gram positif dan 1 Gram negatif. Beberapa genus BPN Gram negatif antara lain: Azomonas, Pseudomonas, Azospirilum, Azotobacter, Beijerinckia, Derxia (Santoso, 2019; Agisti et al., 2014). Isolat BPN yang merupakan gram positif antara lain Kelas Actinobacter yaitu genus Frankia (Sellstedt \& Richau, 2013).
Berdasarkan hasil pengamatan karakterisasi morfologi koloni dan karakterisasi sel yang telah dijelaskan diatas, maka didapatkan 14 isolat terseleksi yang tidak sama untuk di uji biokimia, isolat tersebut meliputi : GA 1, GA 2, GB 2, GB 3, GC 2, LD 1, GH 1, LJ 1, LJ 2, LJ 3, LK 1, LK 2, LL 1, dan LL 2. Hasil pengujian biokimia terhadap isolat bakteri pengikat nitrogen (BPN) terpilih yang meliputi uji TSIA, Sitrat, Katalase, Motilitas dan Urea mendapati hasil yang berbeda-beda. Hasil dapat dilihat pada tabel 2 .

\section{Hasil Uji TSIA}

Uji TSIA dilakukan mengetahui kemampuan bakteri dalam memfermentasikan karbohidrat (glukosa, laktosa, sukrosa, dan pembentukan $\mathrm{H}_{2} \mathrm{~S}$ ). Hasil fermentasi ini diamati pada 2 tempat, yaitu pada bagian miring media dan bagian dasar media. Jika warna merah yang terdapat pada agar menunjukkan reaksi basa, sedangkan jika berwarna kuning pada agar menunjukkan reaksi asam. Warna merah yang terdapat pada bagian permukaan dan warna kuning yang terdapat bagian dasar tabung menunjukkan bahwa terjadinya fermentasi glukosa. Tetapi tidak terjadi fermentasi laktosa dan sukrosa. Hal ini menunjukkan bahwa bakteri hanya mampu memfermentasi sebagian karbohidrat. Kemudian apabila terjadinya warna kuning pada bagian permukaan dan dasar tabung, hal ini menunjukkan terjadinya fermentasi glukosa, laktosa dan sukrosa. Sedangkan warna kuning yang terdapat bagian permukaan dan warna merah pada bagian dasar menunjukkan bahwa bakteri hanya mampu memferementasi laktosa dan sukrosa saja.

Selanjutnya apabila warna merah terdapat pada bagian permukaan dan pada bagian dasar, hal ini menunjukkan bahwa ketiga gula tidak mampu difermentasikan. Untuk pembentukan $\mathrm{H}_{2} \mathrm{~S}$ ditandai dengan terbentuknya endapan warna hitam di dasar media. (Ulfa et al., 2015). Berdasarkan hasil uji biokimia dengan media TSIA bakteri mampu untuk memfermentasi glukosa sebanyak 11 isolat dan tidak mampu untuk memfermentasi glukosa sebanyak 3 isolat. Sedangkan untuk memfermentasi laktosa serta sukrosa hanya diperoleh sebanyak 8 isolat, dan 6 isolat lainnya tidak mampu untuk memfermentasi laktosa dan sukrosa. Semua isolat BPN tidak mampu memproduksi $\mathrm{H}_{2} \mathrm{~S}$.

\section{Hasil Pengujian Sitrat}


Pengujian Sitrat ini dilakukan untuk mengetahui kemampuan dari bakteri dalam menggunakan sitrat sebagai satu-satunya sumber karbon dan energi. Reaksi positif dari pengujian ini ditandai dengan adanya perubahan warna medium dari warna hijau menjadi warna biru. Perubahan warna ini dikarenakan penggunaan sitrat oleh bakteri menyebabkan asam menghilang dari media, sehingga terjadi perubahan warna media dan peningkatan $\mathrm{pH}$ (Ulfa et al., 2015). Untuk hasil pengujian sitrat diperoleh bahwa 9 isolat bereaksi positif ditandai perubahan warna media dari hijau menjadi biru. Sedangkan untuk 5 isolat lainnya tidak mampu mengubah warna dari medium yang menandakan reaksi negatif.

\section{Hasil Uji Katalase}

Uji katalase ini berguna untuk mengetahui keberadaan enzim katalase pada isolat bakteri. Terdapat beberapa bakteri yang mampu untuk menghasilkan peroksidae atau enzim katalase sehingga dapat mendestruksi hidrogen peroksida $\left(\mathrm{H}_{2} \mathrm{O}_{2}\right) . \mathrm{H}_{2} \mathrm{O}_{2}$ memiliki sifat toksik yang mempunyai kemampuan cepat dalam merusak struktur komponen sel bakteri. Oleh dengan itu, enzim katalase bereaksi mengkatalis $\mathrm{H}_{2} \mathrm{O}_{2}$ menjadi $\mathrm{H}_{2}$ dan $\mathrm{O}_{2}$. Reaksi positif dari pengujian ini apabila koloni bakteri yang dicampur dengan $\mathrm{H}_{2} \mathrm{O}_{2}$ terlihat adanya gelembung udara disekitar koloni (Ulfa et al., 2015). Berdasarkan hasil pengujian katalase diketahui 12 isolat menunjukkan hasil positif ditandai dengan terbentuknya gelembung udara, dan 2 isolat lainnya menunjukkan hasil negatif dengan tidak terbentuknya gelembung udara. Genus Azotobacter ditandai dengan uji katalase positif. Karakter utama dari genus Azotobacter ini adalah Gram negatif sel nya berbentuk cocoid, oksidase negatif, katalase positif, kemoorganotrof, bersifat aerob, memiliki alat gerak berupa flagella, dan mampu memfermentasi gula (Yulitaasary, 2017). Azotobacter dapat ditemukan pada habitat tanah dan air. Spesies tertentu bersimbisosis dengan perakaran tanaman, dengan ciri koloni berwarna putih bening, permukaan cembung, tepian koloni rata, dan berbentuk bulat (Agisti et al., 2014). Upadhyay et al. (2015) juga melaporkan bahwa, isolasi Azotobacter dari tanah mendapatkan 32 isolat merupakan Azotobacter bersifat Gram negatif, katalase positif dan 10 isolat Gram positif, katalase negatif. Genus Derxia merupakan karakter utama dengan kunci katalase negatif, oksidase positif dan sel yang berbentuk basil (Agisti et al., 2014).

\section{Uji Motilitas}

Untuk uji motilitas didapatkan hasil 8 isolat positif dan 6 isolat lainnya bersifat negatif. Hasil pengujian motilitas dapat diamati dengan pertumbuhan yang menyebar disekitar tempat penusukan atau tumbuh lurus disekitar penusukan atau pertumbuhan yang menyebar disekitar area tersebut. Motilitas bakteri menunjukkan bakteri tersebut mempunyai flagel (gerak aktif) maupun oleh karena faktor dari luar yaitu adanya Gerak Brown. Gerak Brown merupakan gerakan molekul secara acak yang terdapat pada media (Ulfa et al., 2015). Adapun genus bakteri BPN yang diketahui mempunyai kemampuan motilitas yaitu Pseudomonas, Azospirilumyang tergolong ke dalam bakteri gram negatif (Santosoet al., 2019). Selain itu, genus Azotobacter juga dikenal mempunyai kemampuan motilitas yang tergolong ke dalam bakteri Gram negatif (Agisti et al., 2014). Azotobacter merupakan kelompok Gram negatif dan memiliki flagel peritrik. Bakteri ini terdapat dapat hidup pada habitat tanah dan air (Rahmi, 2014). Selanjutnya Clostridium pateurianum merupakan genus yang bersifat motil yang tergolong ke dalam Gram bakteri Gram positif (Kaburuan et al., 2014).

Tabel 3. Hasil Pengujian Biokimia

\begin{tabular}{|c|c|c|c|c|c|c|c|c|c|}
\hline No. & $\frac{\ddot{\sigma}}{\mathscr{\theta}}$ & $\begin{array}{l}\text { है } \\
\text { है } \\
\frac{\text { E }}{0}\end{array}$ & 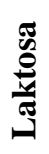 & 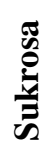 & $\underset{N}{\mathcal{N}}$ & $\underset{\sigma}{\varpi}$ & 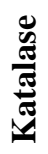 & 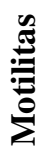 & Dِّ \\
\hline 1 & GA 1 & + & - & - & - & + & + & + & + \\
\hline 2 & GA2 & + & - & - & - & - & + & + & + \\
\hline 3 & GB 2 & - & - & - & - & + & + & + & + \\
\hline 4 & GB 3 & + & + & + & - & - & - & - & + \\
\hline 5 & GC 2 & + & + & + & - & + & - & - & + \\
\hline
\end{tabular}




\begin{tabular}{cccccccccc}
\hline 6 & LD 1 & + & + & + & - & + & + & + & + \\
\hline 7 & GH 1 & + & + & + & - & + & + & + & + \\
\hline 8 & LJ 1 & - & - & - & - & + & + & + & + \\
\hline 9 & LJ 2 & + & + & + & - & - & + & + & + \\
\hline 10 & LJ 3 & + & + & + & - & - & + & - & + \\
\hline 11 & LK 1 & - & - & - & - & + & + & - & + \\
\hline 12 & LK 2 & + & + & + & - & + & + & - & + \\
\hline 13 & LL 1 & + & + & + & - & - & + & - & + \\
\hline 14 & LL 2 & + & - & - & - & + & + & + & + \\
\hline
\end{tabular}

\section{Uji Urea}

Uji urea ini bertujuan untuk mengetahui kemampuan bakteri dalam mendegradasi urea menjadi amoniak. Reaksi positif pada uji ini ditandai dengan perubahan warna medium menjadi merah muda (Ulfa et al., 2015). Perubahan warna ini terjadi pada saat enzim urease memutuskan ikatan karbon dan nitrogen untuk membentuk amoniak. Adanya amoniak ini menyebabkan suasana medium menjadi basa atau alkali. Indikatornya terlihat perubahan media menjadi warna merah muda (Wahyuni et al., 2018). Pada penelitian ini hasil pengujian urease menunjukkan semua isolat bereaksi positif. Hasil ini menunjukkan bahwa isolat yang diperoleh dari hasil penelitian ini merupakan isolat yang potensial untuk dikembangkan dan diaplikasikan sebagai biofertilizier. Karena semua isolat selain mampu mengikat nitrogen tetapi juga mampu mengubah nitrogen menjadi amoniak yang akan digunakan langsung oleh tanaman. Hasil berbeda dari isolasi BPN dari rizosfer tanaman jagung dan padi asal Kabupaten Barru, Sulawesi Selatan mendapatkan 20 isolat. Namun, hanya 9 isolat yang mampu untuk mengekskresikan ammonium ( 2014).

Banyak spesies bakteri mampu menambat nitrogen dari atmosfer tetapi hanya sedikit yang mampu mensekresikan nitrogen dalam bentuk ammonium ke lingkungan, sehingga nitrogen yang tersedia dilingkungan juga masih sedikit. Ammonium yang diekskresikan keluar sel oleh bakteri melalui difusi dapat langsung dimanfaatkan oleh tanaman atau organisme lain. Selain itu tanaman dan organisme lain juga mampu memanfaatkan nitrogen yang telah dilepaskan ke lingkungan yang berasal dari sel bakteri yang mati atau lisis dalam bentuk senyawa nitrogen organik dalam sel seperti protein dan asam nukleat setelah melalui proses mineralisasi (Hartono et al., 2014).
Mikroba diazotroph atau mikroba pengikat nitrogen mempunyai peranan penting pada ekositem lahan gambut oligotrofik (lahan yang mengandung sedikit unsur hara) yang merupakan penampung $\mathrm{CO}_{2}$ dan rentan terhadap perubahan iklim. Kondisi lahan gambut seperti $\mathrm{pH}$ rendah, nitrogen, dan suhu tetapi tetap dapat mendukung mikroba diazotrof disebabkan keberadaan enzim Nitrogenase (Warren et al., 2017). Tanaman tidak dapat langsung mengikat nitrogen dari atmosfer. Unsur nitrogen dapat diserap oleh tanaman dalam bentuk senyawa ammonium $\left(\mathrm{NH}_{4}{ }^{+}\right)$(Hartono et al., 2014). Fiksasi nitrogen adalah proses nitrogen dari atmosfer diubah menjadi amonia dengan bantuan enzim nitrogenase (Sellstedt dan Richau, 2013). Berbagai penelitian mengenai keberadaan dan potensi BPN menunjukkan hasil yang berbedabeda. Keberadaan bakteri ini dipengaruhi oleh faktor kesuburan tanah, $\mathrm{pH}$, kandungan karbon, kandungan nitrogen, Posfor, dan mikronutrien, serta aerasi tanah (Widawati dan Suliasih, 2019).

Isolat pada penelitian ini diperoleh 25 isolat yang kemudian terseleksi kembali hingga memperoleh 14 isolat BPN. Pada penelitian mengenai isolasi BPN pada tanah rizosfer tanaman di Gunung Salak, Bogor memperoleh hasil sebanyak 30 isolat (Widawati, 2015). BPN dari rizosfer tumbuhan Poacea pantai mendapatkan hasil 8 isolat (Hutapea, 2018). Bakteri Pengikat Nitrogen dari hasil isolasi perakaran padi di Kelurahan Balang Kecamatan Binamu, Kabupaten Jeneponto melaporkan bahwa mendapatkan 4 isolat (Malombasi, 2018). Isolat BPN pada penelitian yang dilakukan pada tanah Marginal di Kalimantan Tengah menunjukkan bahwa pada akar tanaman karamunting di tanah gambut dan tanaman masisin di tanah berpasir mendapat 6 isolat, dan memperoleh 5 isolat pada tanaman karamunting dari tanah mineral podsol merah 
kuning dan pada tanah berpasir (Pidjath et al., 2014).

Selain itu, BPN hasil penelitian dari tanah bekas tanaman bawang merah melaporkan hanya mendapatkan 3 isolat (Karina, 2016). Hasil penelitian BPN juga dilaporkan dari tanah perkebunan kelapa sawit di Desa Air Bening Kabupaten Musi Rawas memperoleh 10 isolat terpilih (Maria, 2019). Tidak hanya itu, BPN dari hasil isolasi pada lahan restorasi dengan metode Legume Cover Crop (LCC) di daerah Pasirian Lumajang Jawa Timur mendapatkan sebanyak 20 isolat (Agisti et al., 2014). Kemudian, BPN dari hasil penelitian yang diperoleh dari tanah hutan mangrove sungai Peniti, Kabupaten Mempawah melaporkan bahwa mendapatkan 3 isolat (Santoso et al., 2019). Bakteri pengikat nitrogen dapat bersimbiosis dengan organisme lain misalnya Rhizobium yang berasosiasi dengan akar Leguminase, dan ada yang bersifat non simbion misalnya Azobacter dan Azomonas yang hidup pada berbagai tipe tanah (Widawati dan Suliasih, 2019).

Hasil penelitian ini secara umum belum dapat menyimpulkan jenis isolat yang diperoleh sampai pada tingkatan genus. Akan tetapi berdasarkan pengamatan morfologi koloni dan sel, serta pewarnaan Gram dan beberapa pengujian biokimia, beberapa isolat teridentifikasi mengarah pada genus bakteri Gram negatif Azotobacter, Azomonas, Beijerinckia, Frankia, dan bakteri Gram positif pengikat nitrogen berasal dari Kelas Actinobacter. Isolat hasil pengamatan yang telah dilakukan didapatkan bahwa isolat dengan kode GA 1 diidentifikasi mengarah pada genus Azotobacter. Azotobacter merupakan bakteri non simbiotik yang hidup disekitar perakaran dan memiliki kemampuan tinggi dalam menambat nitrogen, serta dapat hidup di lingkungan aerob maupun anaerob fakultatif, merupakan Gram negatif, terdapat pada tanah maupun perairan. Isolat dengan kode GA 2, GB 2, LD 1, LJ 1, dan LL 2 mengarah pada golongan genus Azomonas, dan LJ 3 mengarah pada genus Beijerinckia. Agisti et al., (2014) menyatakan Azomonas merupakan spesies bakteri pengikat nitrogen dari atmosfer dalam kondisi aerob. Memiliki flagel, dapat bersifat Gram negatif atau positif usia kultur. Katalase positif, dapat hidup pada $\mathrm{pH} 4,6-4,8$. Beberapa isolat pada penelitiannya mempunyai warna putih kemerahan, bentuk koloni coccus, permukaan cembung dan tepian utuh, cenderung tergolong genus Beijerinckia. Karakter utama genus Beijerinckia adalah gram negatif, oksidase positif, katalase positif dan bentuk sel basil.

Isolat dengan kode GH 1 mengarah pada genus dari Frankia yang merupakan anggota Actinobacter. Kelas Actinobacter merupakan bakteri Gram positif yang juga mampu mengikat nitrogen (Sellstedt dan Richau, 2013), terdiri dari 16 ordo yaitu, Bifidobacteriales, Catenulisporales, Corynebac-teriales, Frankiales, Glycomycetales, Propioni-bacteriales, Jiangellales, Kineosporiales, Micro-coccales, Micromonosporales, Actinomycetales, Actinopolysporales, Pseudonocardiales, Strepto-mycetales, Streptosporangiales, dan Incertae sedis. Koloninya membentuk hifa seperti fungi. Memiliki warna yang bervariasi kuning, coklat, merah, merah jambu, hijau dan hitam. Dapat tumbuh pada temperatur optimal $20^{\circ} \mathrm{C}-42^{\circ} \mathrm{C}$, pH optimum 4,5-5,5. Salah satu genusnya yaitu Frankia yang mampu memfiksasi nitrogen (Anandan et al., 2016). Frankia yang merupakan Gram positif juga mampu mengikat nitrogen dalam kondisi simbiotik dan non simbiotik. Selain itu, nonsimbiotik Frankiales seperti Modestobacter marinus, Blastococcus saxo-obsidens, Acidothermus cellulolyticus, dan Geodermatophilus obscurus (Sellstedt dan Richau, 2013).

\section{SIMPULAN}

Isolasi BPN yang diperoleh dari lokasi penelitian berjumlah 25 isolat, dengan bentuk morfologi koloni dan sel yang bervariasi. Hasil pengujian biokimia menunjukkan kemampuan bakteri yang berbeda-beda dalam memfermentasi media uji biokimia. Pada pengujian urease semua isolat positif mampu mendegradasi urea menjadi amoniak, sehingga potensial untuk dikembangkan menjadi biofertilisier. Perlu dilakukan pengujian potensi isolat dalam memfiksasi Nitrogen dan kelanjutan proses identifikasi BPN asal tanah gambut hingga tingkat spesies.

\section{REFERENSI}

Agisti A., Alami N.H., Hidayati T.N.2014. Isolasi dan Dentifiasi Bakteri Penambat 
Nitrogen Non Simbiotik pada Lahan Restorasi dengan Metode Legume Cover Crop (LCC) di Daerah Pasirian Lumajang Jawa Timur. Jurnal Sains dan Seni POMITS.Vol.3 (2).

Agus F., Markus, A., Ali, J dan Masganti. 2016. Lahan Gambut Indonesia: IAARD Press. ISBN 978-602-344-034-4. IAARD Press: Balai Penelitian Dan Pengembangan Pertanian Kementerian Pertanian.

Anandan R., Dharumadurai D., Manogaran G.P.2016. An Introduction to Actinobacteria. Doi: 10.5772/62329.

Bakteri Penambat N Pada Pusat Lokasi Tanaman Kedelai Edamane (Glycine $\max ($ L.) Merr.) Kabupaten Jember. Journal of Applied Agricultural Sciences. Vol. 1 (2).

Erlansyah, 2017. Pengolahan Gambut Menjadi Lahan Pertanian. Balai Pengamatan Dirgantara Pontianak. http://repository.lapan.go.id/index.php? $\mathrm{p}=$ show_detail\&id=167. Diakses 27 April 2020.

Fajrin, V.N.A., Erdiansyah, I., dan Damanhuri. 2017. Koleksi Dan Identifikasi

Hartono dan Jumadi .2014. Seleksi dan Karakterisasi Bakteri Penambat Nitrogen NonSimbiotik Pengekskresi Amonium Pada Tanah Pertanaman Jagung (Zea mays L.) dan Padi (Oryza sativa L.) Asal Kabupaten Barru, Sulawesi Selatan. Jurnal Sainsmat Vol.3 (2).

Huslina, F. dan Harahap, D. 2019. Isolasi Bakteri Pengikat Nitrogen Dengan Menggunakan Media Jensen. Jurnal Agrotek. Vol. 6 (2).

Hutapea A. J. 2018. Potensi Bakteri Pelarut Fosfat, Pengikat Nitrogen Dan Penghasil Hormon IAA Dari Rhizosfer Tumbuhan Poaceae Pantai Dalam Meningkatkan Pertumbuhan Padi (Oryza sativa L.). Skripsi. Universitas Sumatera Utara: Fakultas Matematika Dan Ilmu Pengetahuan Alam.

Indonesia Forest and Climate Support (IFACS). 2014. Rencana Konservasi Bentang Alam Kabupaten Aceh Selatan Provinsi Aceh. United States Agency International Development (USAID).

Irfan, M. 2014. Isolasi Dan Enumerasi Bakteri Tanah Gambut Di Perkebunan Kelapa
Sawit PT. Tambang Hijau Kecamatan Tambang Kabupaten Kampar. Jurnal Agroteknologi. Vol 5 (1).

Islam H., Nelvia, Zul D.2019. Isolasi dan Uji Potensi Bakteri Diazotrof non Simbiotik Asal Tanah Kebun Kelapa Sawit dengan Aplikasi Tandan Kosong dan Limbah Cair Pabrik Kelapa Sawit. Jurnal Agroteknologi. Vol. 9 (2).

Ismiati. 2018. Isolasi Dan Karakteristik Bakteri Pada Air Gambut Di Kawasan Desa Sungai Daun Kecamatan Pasir Limau Kapas Kabupaten Rokan Hilir Provinsi Riau. Skripsi. Medan: Universitas Medan Area.

Kaburuan R., Hapsoh, dan Gusmawartati. 2014. Isolasi Dan Karakterisasi Bakteri Penambat Nitrogen Simbiotik Tanah Gambut Cagar Biosfer Giam Siak Kecil Bukit Batu. Jurnal Agroteknologi. Vol 5 (1).

Karina A. I. 2016. Isolasi Dan Identifikasi Bakteri Penambat Nitrogen Pelarut Fosfat, Dan Bakteri Pendegradasi Selulosa Pada Tanah Bekas Tanaman Bawang Merah Allium cepa L. Yang Diberi Biofertilizer. Skripsi. Jakarta: Fakultas Sains Dan Teknologi Universitas Airlangga.

Mahdiyah, D. 2015. Isolasi Bakteri Dari Tanah Gambut Penghasil Enzim Protease. Jurnal Pharma science. Vol 2 (2).

Malombasi N.A. 2018. Isolasi Dan Identifikasi Bakteri Penambat Nitrogen Non Simbiotik Daerah Perakaran Padi (Oryza sativa) Di Kelurahan Balang Kecamatan Binamu Kabupaten Jeneponto. Skripsi. UIN Alauddin Makassar: Fakultas Sains Dan Teknologi.

Maria A. 2019. Isolasi Dan Identifikasi Bakteri Penambat Nitrogen Dari Tanah Perkebunan Kelapa Sawit Di Desa Air Bening Kabupaten Musi Rawas Dan Sumbangan Pada Proses Pembelajaran Di SMA Negeri 2 Palembang. Skripsi. Universitas Muhammadiyah Palembang: Fakultas Keguruan Dan Ilmu Pendidikan.

Pidjath C., dan Nion A.Y. 2014. Isolasi Bakteri Pengikat Nitrogen Dari Tanah Marginal di Kalimantan Tengah. Jurnal Agripeat. Vol. 15 (2). 
Pratita M, Y. E., dan Putra S. R. 2012. Isolasi Dan Identifikasi Bakteri Termofilik Dari Sumber Mata Air Panas Di Songgoriti Setelah Dua Hari Inkubasi. Jurnal Teknik omits. Vol. 1(1).

Pratiwi E., Satwika T. D., \& Agus F.2018. Keanekaragaman Mikroba Tanah Gambut di Bawah Hutan dan di Bawah Perkebunan Sawit di Provinsi Jambi. ISSN 1410-7244.

Rahmi SP.MP. 2014. Kajian Efektifitas Mikroba Azotobacter sp. Sebagai Pemacu Pertumbuhan Tanaman Kakao (Theobroma cacao L.) Jurnal Galung Tropika.Vol. 3 (2).

Ritung, S., \& Sukarman, 2016. Kesesuaian Lahan Gambut Untuk Pertanian. IAARD Press, ISBN 978-602-344-034-4.

Rohyani., Delita, Z dan Fibrianti, B. L. 2014. Isolasi Bakteri Indigenus Yang Potensial Sebagai Agen Biofertilizer Asal Tanah Gambut di Kawasan Zamrud Dan Taman Nasional Tesso Nilo, Riau. JOM FMIPA. Vol. 1 (2).

Santoso, K., Rahmawati, dan Rafdinal. 2019. Eksplorasi Bakteri Penambat Nitrogen Dari Tanah Hutan Mangrove Sungai Peniti, Kabupaten Mempawah. Protobiont. Vol. 8 (1).

Sari R. D. 2015. Isolasi Dan Identifikasi Bakteri Tanah Yang Terdapat Di Sekitar Perakaran Tanaman. Bio-site. Vol. 1 (1).

Sellstedt A., \& Richau K.H.2013. MINIREVIEW Aspects of nitrogen fixing Actinobacteria, in particular free-living and symbiotic Frankia. FEMS Microbiol Lett 342 (2013) 179-186. DOI: 10.1111/1574-6968.12116.

Ulfa A., Suarsini, E., dan Irawati, M. H. A. M. 2015. Isolasi Dan Uji Sensitivitas Merkuri Pada Bakteri Dari Limbah Penambangan Emas Di Sekotong Barat Kabupaten Lombok Barat: Penelitian Pendahuluan. Proceeding Biology Educatin Conference. Vol.13 (1).

Upadhyay S., Kumar N., Singh V.K., \& Singh A.2015. Isolation, characterization and morphological study of Azotobacter isolates. Journal of Applied and Natural Science.Vol. 7 (2).

Wahyuni R. M., Sayuti A., Abrar, M., Erina, dan Zainuddin, M.H. 2018. Isolasi Dan Identifikasi Bakteri Enterik Patogen
Pada Badak Sumatera (Dicerorhinus sumatrensis) Di Suaka Rhino Sumatera Taman Nasional Way Kambas (TNWK), Lampung. JIMVET. Vol. 2(4).

Warren M.J., Lin X., Gaby J.C., Kretz C.B., Kolton M., Morton P. L., Pett-Ridge J., Westo D.J., Kostka J.E., Glass J.B.2017. Molybdenumbased diazotrophy in a Sphagnum peatland in northern Minnesota. Applied and Environmental

Microbiology doi: https://doi.org/10.110 1/114918.

Widawati S. 2015. Uji Bakteri Simbiotik Dan Non Simbiotik Pelarutan Ca vs. P Dan Efek Inokulasi Bakteri Pada Anakan Turi (Sesbania grandifora L. Pers). J. Biologi Indonesia. Vol. 11 (2).

Widawati S., dan Suliasih, 2019. Role of Indigenous Nitrogen-fixing Bacteria in Promoting Plant Growth on Post Tin Mining Soil. Makara Journal of Science, 23/1 28-38 doi: 10.7454/mss.v23i1.1080128.

Yulitaasary A.T., Asyiah I.N., Iqbal M.2017. Isolasi dan Identifikasi AzotobacterDari Rhizosfer Tanaman Kopi (Coffea canephora) Yang Terserang Nematoda Parasit Pratylenchus coffeae. Saintifika. Vol.19 (2).

Yuwati T.W. 2016. Restorasi Lahan Gambut. Artikel: Keanekaragaman Mikroba Di Hutan Rawa Gambut Gerunggang Jenis Potensial Untuk Restorasi Lahan Gambut. Bekantan. Vol 4 (1). 